\title{
Identification of a protist-coral association and its possible ecological role
}

\author{
E. Kramarsky-Winter ${ }^{1}$, M. Harel ${ }^{2}$, N. Siboni' ${ }^{2}$, E. Ben Dov ${ }^{2}$, I. Brickner ${ }^{1}$, \\ Y. Loya ${ }^{1}$, A. Kushmaro ${ }^{2, *}$ \\ ${ }^{1}$ Department of Biotechnology Engineering, Faculty of Engineering Sciences, Ben Gurion University, \\ Beer Sheva 84105, Israel \\ ${ }^{2}$ Department of Zoology, George S. Wise Faculty of Life Sciences, Tel Aviv University, Tel Aviv 69978, Israel
}

\begin{abstract}
Recent investigations of coral-associated microbial communities have revealed that coral surfaces are replete with microorganisms that may play important roles in colony wellbeing. In this study we show that the surfaces of a number of large polyped coral species are covered by a layer of aggregate-like microorganisms. These microorganisms are embedded in the mucus and in the tissue of solitary coral Fungia granulosa and in a number of faviid species. They are found on the coral surface and in the coral tissue. They are dispersed in a patchy distribution, with the highest density occurring in the area of the polyp mouth. Microscopic investigation revealed that the microorganisms found on and in tissues of $F$. granulosa are approximately 5 to $30 \mu \mathrm{m}$ in diameter and are made up of unique coccoid bodies of approximately $1 \mu \mathrm{m}$ in diameter. Transmission electron microscopy (TEM) revealed that they contain a nucleus, mitochondria and golgi, indicating they are eukaryotic in nature. The morphological data lead us to identify these organisms as stramenopile protists. This premise was strengthened by molecular investigation of samples taken from the surface mucus of the coral F. granulosa. The possible role of these protists is discussed.
\end{abstract}

KEY WORDS: Coral $\cdot$ Protist $\cdot$ Stramenopile aggregates $\cdot$ Nutrition $\cdot$ Mucus

\section{INTRODUCTION}

A number of studies have shown that there is a dynamic microbial biota living on the surface and in the tissue of many coral species (Ritchie \& Smith 1997, Kushmaro et al. 1999, Rohwer et al. 2001), though their role in the reef ecosystem remains, for the large part, a mystery. Microbes may be saprophytic, or pathogenic, or they may provide other important functions in the ecosystem (Kushmaro et al. 1996, Santavy \& Peters 1997, Harvell et al. 1999). One possible function of microorganisms found on coral surfaces may be to provide it with protection from pathogens by interspecific competition and secretion of antibiotic substances (Rohwer et al. 2002). Another role for these microorganisms may be to supply the coral with nitrogen and phosphorous not provided by their symbiotic zooxanthellae (Sorokin 1973a,b, 1978, 1990, Sebens 1994, Schlichter \& Brendelberger 1998,
Anthony 1999, 2000, Rosenfeld et al. 1999, Anthony \& Fabricius 2000). The transfer of such nutrients may occur via the highly productive, mucus-rich micro-layer which extends a few millimeters above the surface tissue of the coral (Paul et al. 1986) and which aids the coral in entangling prey or particulate food that is then collected by the coral's mesenterial filaments (Schlichter \& Brendelberger 1998, Goldberg 2002). This mucus layer may also act as a growth medium for microorganisms.

White patches or coating covering parts of the surface of a number of large polyped scleractinian coral species have recently been observed in the Gulf of Eilat (Fig. 1, authors' pers. obs.). Upon further examination this white coating was discovered to be made up of discreet aggregates of unusual coccoid bodies bound within a membrane. This paper describes these 'aggregate-like' microorganisms, their distribution, and their possible function in the reef ecosystem. 


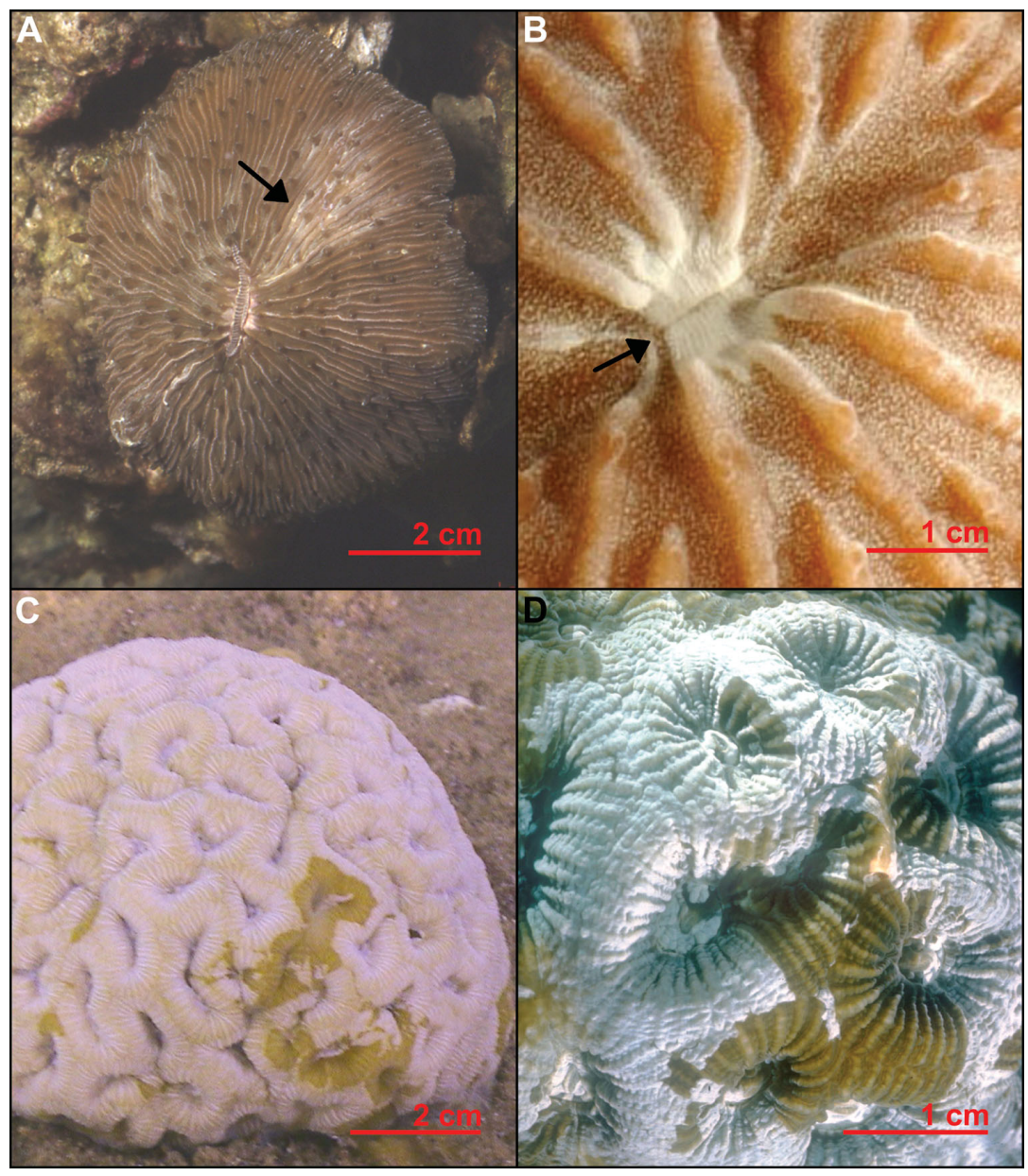

Fig. 1. Corals with aggregate coating. (A) Fungia granulosa (arrow: high concentration of aggregates); (B) F. granulosa, close up of mouth area with high concentration of aggregates (arrow); (C) Coscinarea sp.; and (D) Favia favus; the white covering is mucus packed with aggregates

\section{MATERIALS AND METHODS}

In order to examine the prevalence of coral coverage by the white coating, ten $10 \mathrm{~m}^{2}$ belt transects (see Loya 1978) were carried out in the shallow reefs near the $H$. Steinitz Marine Laboratory at Eilat, Israel, at depths of 0.5 to $5 \mathrm{~m}$. The species of corals covered by this type of coating were recorded, as well as their numbers. In addition, individuals of the fungiid coral Fungia granulosa were collected and examined under a dissecting scope in the laboratory. Small colonies of the faviid Favia favus were also examined. The white coating was microscopically observed to be made up of discreet aggregates of unusual coccoid bodies.

Aggregate dynamics on adult corals. To ascertain if these aggregates are static or if their numbers change with time, 6 adult specimens of the coral Fungia granulosa were collected and maintained in the laboratory under a controlled temperature $\left(24^{\circ} \mathrm{C}\right)$ and light re- gime (12:12 h light:dark). Water was changed every $3 \mathrm{~d}$ using $0.2 \mu \mathrm{m}$ filtered Eilat seawater. The corals were photographed at the same magnification immediately after collection and then monthly for a period of 3 mo. A grid was placed over each photograph, the number of aggregates was counted in 10 randomly chosen squares and the average number of aggregates $/ \mathrm{cm}^{2}$ was calculated. To ascertain if these microorganisms may have a role in coral wellbeing, bleaching was induced in 3 additional corals. This was done by covering the aquaria containing the corals in $0.2 \mu \mathrm{m}$ filtered seawater (changed every $3 \mathrm{~d}$ ) with black plastic sheets for a period of 3 to $6 \mathrm{mo}$, until complete bleaching was achieved (as assayed visually). The corals were not fed at this time. The appearance of the aggregates was evaluated visually under a dissecting scope at the end of this period.

Aggregate dynamics on coral tissue fragments. In order to be able to determine microscopic changes in the dynamics of the aggregate position on or in the corals, tissue fragments were removed from 3 fungiid corals using forceps and fine scissors. The fragments were placed in petri dishes with $0.2 \mu \mathrm{m}$ filtered seawater under laboratory lighting. Water was changed every other day. Once the tissue fragments became round and formed motile tissue balls, they were allowed to settle and attach to the substrate (see Kramarsky-Winter \& Loya 1996). The tissue balls were monitored and photographed periodically under a dissecting scope. A number of these tissue balls were fixed in $2.5 \%$ gluteraldehyde in seawater embedded in $1 \%$ agarose and processed for histology and electron microscopy (transmission and scanning electron microscopy, TEM and SEM).

Identification of the aggregates. A sterile swab was used to collect mucus and surface cells from areas on the coral that had high aggregate density. Mucus alone was collected by milking the coral, i.e. inverting them over a sterile funnel and collecting the mucus drip. The mucus was then centrifuged and rinsed in sterile seawater and the aggregates collected at the bottom of the tube were fixed in $2.5 \%$ gluteraldehyde for TEM and processed as above. Mucus samples 
laden with aggregates were stained with acridine orange and DAPI and viewed microscopically. Further identification of these organisms was carried out using both morphological and molecular tools. For molecular work, samples were collected from the coral surface using bacteriological loops. These samples were made up of mucus, coral cells and surface microorganisms. The samples were then washed a number of times with sterile seawater placed in ethanol and DNA extraction was carried out using NucleoFood Spin (Machery-Nagel) and stored at $-80^{\circ} \mathrm{C}$. rDNA was amplified from all samples using general and specific (stramenopile) 18S rDNA primers (see Table 1) in order to ascertain taxonomic identity. Relevant bands were excised from the $1 \%$ agarose gel and eluted using Wizard SVGel and PCR Clean-Up System (Promega). PCR products were either sequenced directly or were cloned using pGEM-T Easy Vector Systems.

\section{RESULTS}

The white coating that covered the coral surface was made up of aggregates of round bodies embedded in the coral mucus and in the surface of the coral tissue (Figs. 1 to 3). In situ $10 \mathrm{~m}^{2}$ belt transects in shallow waters from 3 reef sites showed that approximately $32 \%$ of shallow water massive corals are infested with dense populations of these aggregate-like granular microorganisms. Coral families with high incidence of aggregate coverage include the large polyped corals belonging to the fungiid and faviid genera (Fig. 1). In our study site a careful examination of corals from 25 belt transects $\left(10 \mathrm{~m}^{2}\right.$ each $)$ revealed that in shallow water of up to $6 \mathrm{~m}, 49.8 \%$ of the Favia sp. ( $\mathrm{n}=231), 31 \%$ of the Acanthastrea sp. (n=39) and $16 \%$ of the Favites sp. (n =56) were covered by this coating. Aggregate coverage ranged from a patchy distribution on the coral sur-
Table 1. Primers used in the PCR procedures

\begin{tabular}{|c|c|c|}
\hline Primer & Sequence $\left(3^{\prime} 5^{\prime}\right)$ & $\begin{array}{c}\text { Target } \\
\text { (18S rDNA) }\end{array}$ \\
\hline NSF-370 & AGGGTTCGATTCCGGAGA & General eukaryote \\
\hline NSFR-1787 & CCGCAGGTTCACCTACGG & General eukaryote \\
\hline NSF-4 & CTGGTTGATCCTGCCAGT & General eukaryote \\
\hline Lab $83 \mathrm{~F}$ & GAAACTGCGAACGGCTCATTA & Stramenopiles \\
\hline Lab-1017 R & GACTACGATGGTATCTAATCATCTTCG & Stramenopiles \\
\hline Thr404f $\mathrm{f}^{\mathrm{a}}$ & CTGAGAGACGGCTACCACATCCAAGG & Thtraustochytridae \\
\hline Thr1017r $\mathrm{r}^{\mathrm{a}}$ & GACTACGATGGTATCTAATCATCTTCG & Thtraustochytridae \\
\hline
\end{tabular}

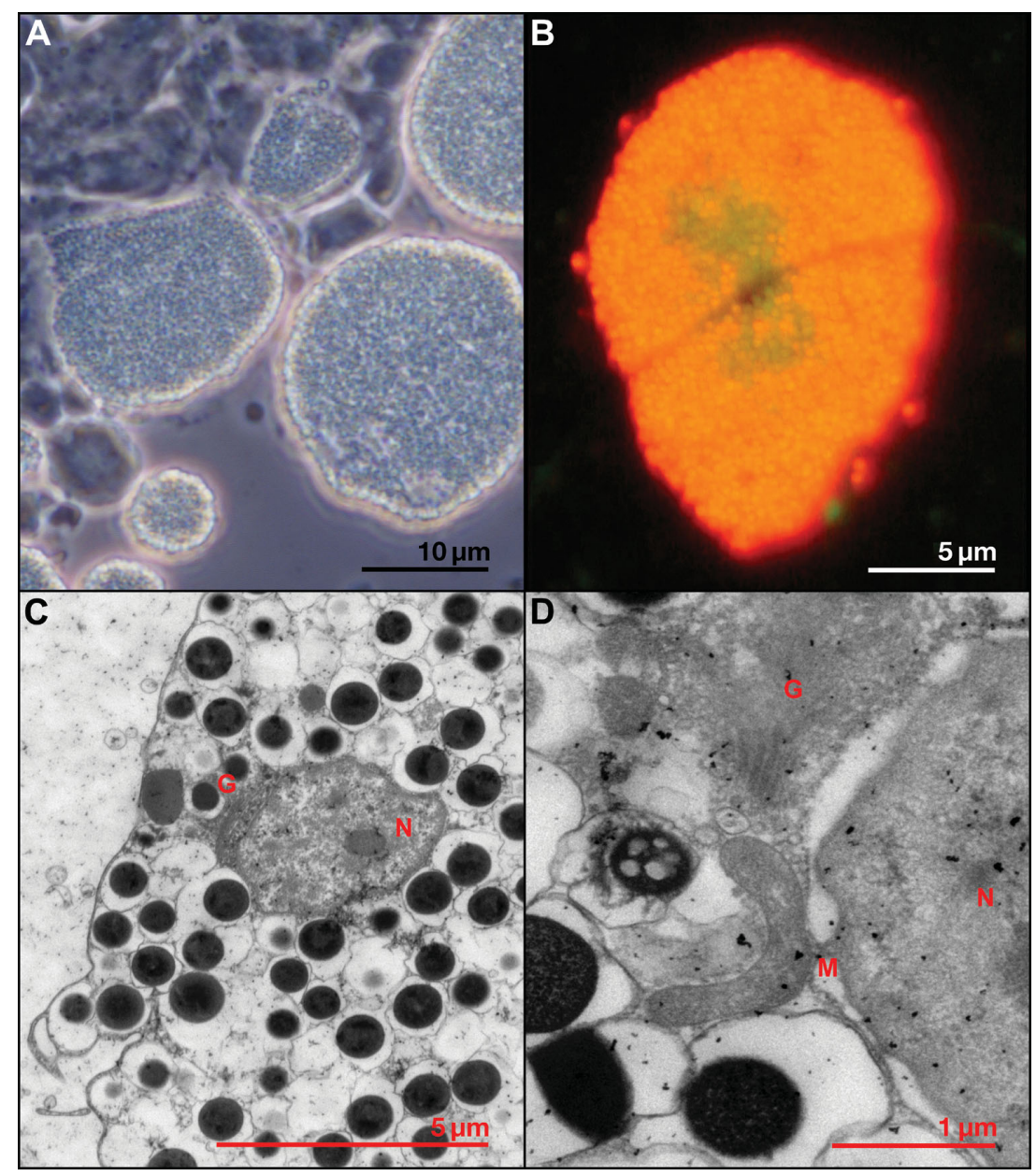

Fig. 2. Protist from Fungia granulosa coral mucus. (A) Phase contrast micrograph of the organisms. (B) Fluorescent micrograph of an acridine orange-stained protist from fungiid coral. (C) Transmission electron micrograph (TEM) of a single protist. Note the nucleus (N) and golgi (G). (D) Higher magnification TEM of the protist. Note nucleus (N), golgi $(\mathrm{G})$, and mitochondrion (M)

face to a complete coating of the coral colony (see Fig. 1) and all the corals appeared healthy.

To date, all of the Fungia granulosa examined microscopically were covered to some extent by these gran- 


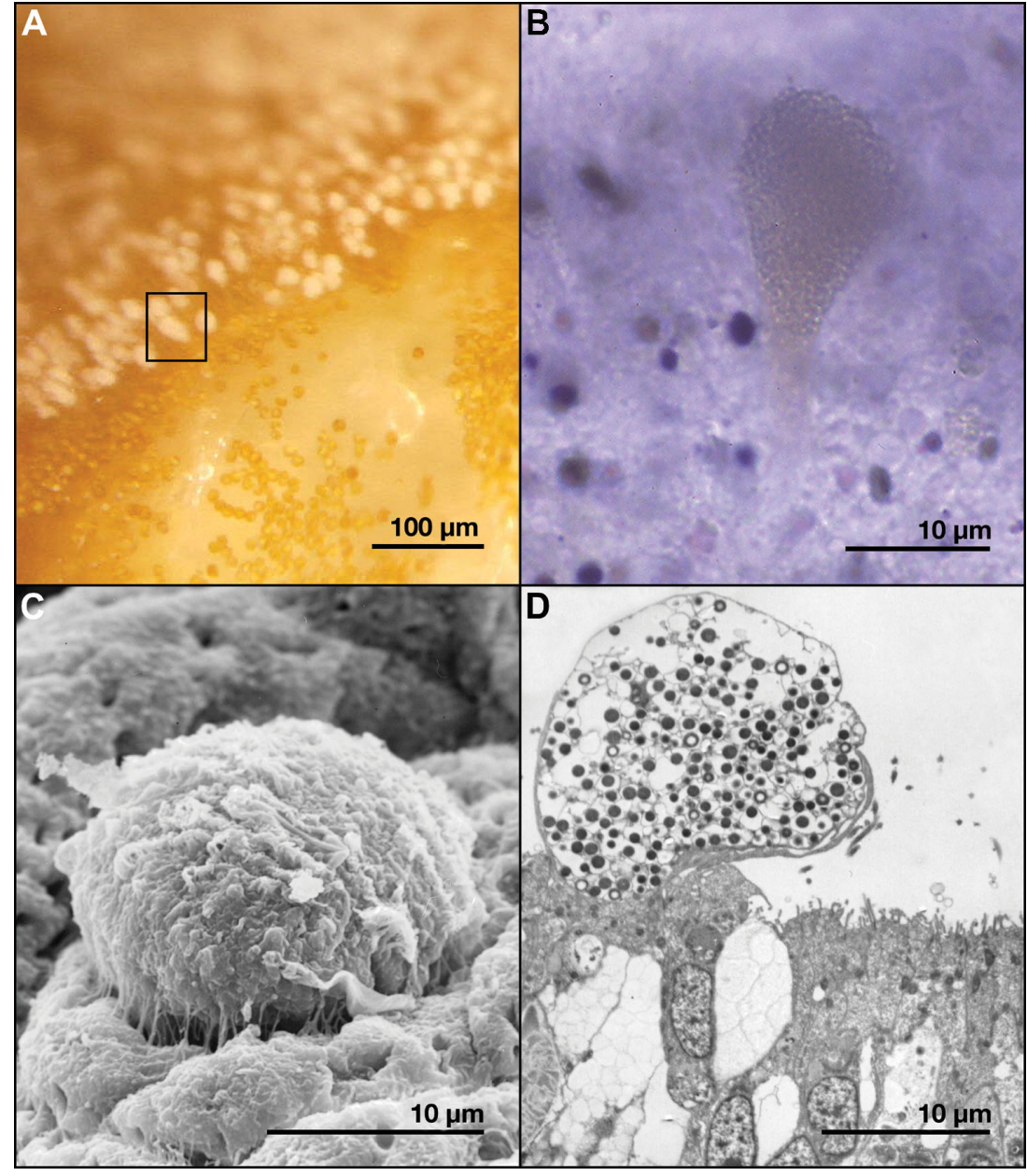

Fig. 3. Protist embedded in the epidermis of Fungia granulosa. (A) Large number of protists embedded in the epidermis of $F$. granulosa. Note the zooxanthellae in gastrodermis. Black box denotes a single aggregate. (B) Photomicrograph of a single protist embedded in the coral epidermis stained by toluidine blue. (C) Scanning electron micrograph of a protist embedded in the coral epidermis. (D) Transmission electron micrograph of a protist showing its nucleus. Note that the coccoid bodies are encased in a membrane, and the cell body is actually embedded in the coral tissue

ular microorganisms, which were dispersed in a patchy distribution, with the highest density occurring in the area of the polyp mouth (Fig. 1B). An examination of the surface of the coral surface revealed a range of $5 \times$ $10^{3}$ to $13 \times 10^{3}$ aggregate-like granular microorganisms per $\mathrm{cm}^{2}$ surface tissue. This did not include the mouth region, where the concentration of these microorganisms formed a thick layer that was too dense to count (Fig. 1B).

The microorganisms found in the coral mucus ranged between 5 and $30 \mu \mathrm{m}$ in diameter (Fig. 2). Light microscopy (LM) revealed aggregates of unique coccoid bodies (Fig. 2A) that, when investigated microscopically for an extended period, underwent lysis, resulting in the release of small subunits.
This presumably occurred due to heat from the microscope lamp. Once they burst open, a number of non-motile spore-like entities (similar to aplanospores) surrounded by a membrane were evident. Acridine orange staining revealed that each component (coccoid unit) contained nucleic acids (Fig. 2B). TEM revealed that the aggregates were made up of rounded coccoid bodies approximately $1 \mu \mathrm{m}$ in diameter enclosed in a membrane (Fig. 2C). Some of these coccoid bodies were found surrounding a nucleus and were enveloped by a thin layer of cytoplasm. Mitochondria of the tubular cristae type were evident, and golgi complexes were found adjacent to the nucleus (Fig. 2C,D). The presence of these subcellular organelles identified these organisms as protists.

Similar organisms were also found embedded in the Fungia granulose polyp surface tissue (Fig. 3), in the epidermis as well as in the gastrodermis (Fig. 4B). LM and TEM revealed that these microorganisms also were made up of unique coccoid bodies (Fig. 3A,B) and had all the subcellular organelles found in organisms from the mucus. They appeared embedded in the coral tissue or as cells enveloped by the coral cells (Fig. 3C,D).

An attempt was made to identify these organisms by molecular means. Using the $18 \mathrm{~S}$ rDNA primers (see Table 1), we identified microorganisms from coral mucus replete with these aggregates. This molecular technique led us to identify a variety of protists with high similarities to known stramenopiles (Leander $\&$ Porter 2001) (see Table 2). Even though the mucus samples were rinsed with sterile seawater in order to remove loosely attached microorganisms, the molecular data may also have included opportunistic species from the surrounding seawater environment. In addition to the identification of stramenopiles as presented in Table 2, our 18s rDNA clone library mainly identified sequences belonging to corals and Symbiodinium spp. Repeated attempts to isolate and culture these stramenopiles have been unsuccessful to date, thus hindering specific molecular identification. 


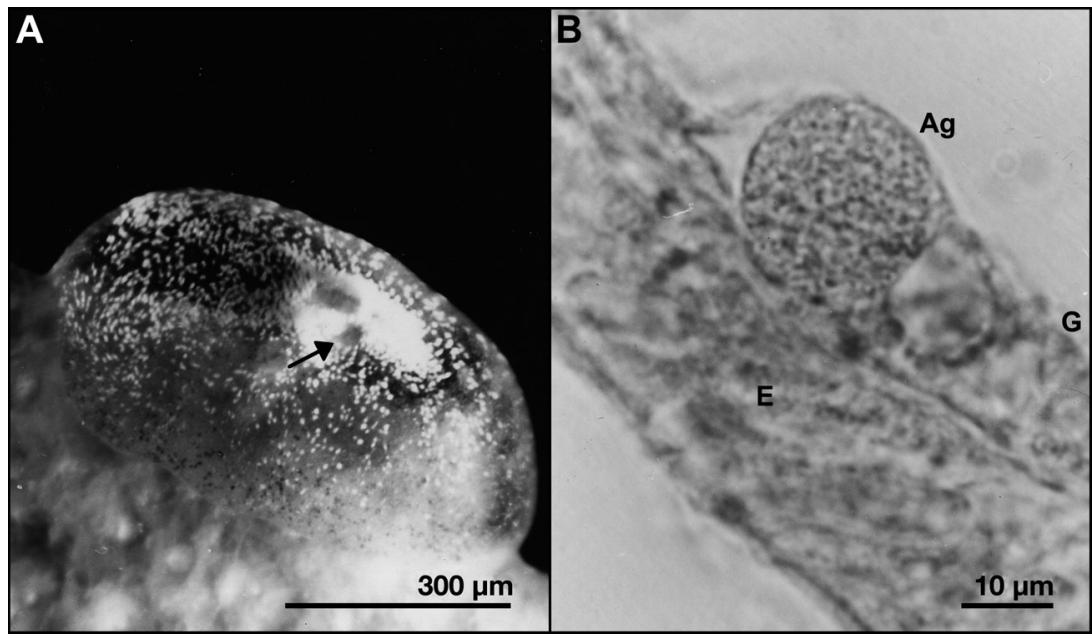

Fig. 4. Primary polyp developing from tissue fragments of Fungia granulosa. (A) Aggregates are dispersed on the body surface, as fluorescing bodies. Note the high density surrounding the developing mouth (arrow). (B) F. granulosa histological section demonstrating an aggregate $(\mathrm{Ag})$ in the coral gastroderm (G). E: coral ectoderm

balls, density was consistently highest around the polyp mouth. In addition, corals that had undergone laboratory-induced bleaching retained the protist community on their surface for over $6 \mathrm{mo}$, but the range of protist cell diameter was reduced to 5-10 $\mu \mathrm{m}$. The protist density remained highest in the mouth region of the polyp.

\section{DISCUSSION}

Morphological and ultrastuctural examination of the organisms found in mucus and on the coral surface suggest that these organisms are unicellular heterotrophes belonging to the stramenopiles, a group of protists that are common in the

The presence of these protists on the coral surface did not seem have any deleterious effects on the corals. Indeed, they were found in tissue fragments that had been excised from adult specimens and had remained viable for weeks without external nourishment (Fig. 4A). These fragments became round and formed tissue balls that remained viable and settled after a few weeks. A dynamic change in the protist density and position was observed over time in these tissue ball cultures. Once a mouth was formed in the settled tissue marine environment (Moss 1986, Raghukumar 2002). This may be corroborated in part by the molecular data collected from the prevalent eukaryotic microorganisms found in the coral mucus. The role of protists in the marine ecosystem is not yet fully understood. Some studies indicate that they may play important roles as alternative food sources for pico- or nano-plankton feeders, and as active degraders and consumers in aquatic microbial food chains (Ferrier-Pagès \& Gattuso 1998, Naganuma et al. 1998, Houlbreque et al. 2004).

Table 2. GeneBank similarity of eukaryote sequences from organisms in aggregate samples from the surface and in mucus collected from the coral Fungia granulosa

\begin{tabular}{|c|c|c|c|c|c|}
\hline $\begin{array}{l}\text { Source } \\
\text { (collection } \\
\text { method) }\end{array}$ & $\begin{array}{c}\text { Primers } \\
\text { 18S rRNA gene }\end{array}$ & $\begin{array}{l}\text { Accession } \\
\text { no. }\end{array}$ & $\begin{array}{l}\text { Sequence } \\
\text { length (bp) }\end{array}$ & Phylogenetics & $\begin{array}{l}\text { Closest relative } \\
\text { and accession no. } \\
\text { (\% similarity) }\end{array}$ \\
\hline $\begin{array}{l}\text { Coral surface } \\
\text { (quadloop) }\end{array}$ & General & DQ073061 & 1230 & $\begin{array}{c}\text { Stramenopiles } \\
\text { Hyphochytriomycetes }\end{array}$ & $\begin{array}{c}\text { Hyphochytrium } \\
\text { catenoides X80344 } \\
(92 \%)\end{array}$ \\
\hline $\begin{array}{l}\text { Mucus } \\
\text { (pipette) }\end{array}$ & Specific & DQ073057 & 717 & $\begin{array}{l}\text { Stramenopiles } \\
\text { Pinguiophyceae }\end{array}$ & $\begin{array}{c}\text { Pinguiococcus } \\
\text { pyrenoidosus AF438324 } \\
(98 \%)\end{array}$ \\
\hline $\begin{array}{l}\text { Mucus } \\
\text { (pipette) }\end{array}$ & Specific & DQ073058 & 579 & $\begin{array}{l}\text { Stramenopiles } \\
\text { Labyrinthulida }\end{array}$ & $\begin{array}{c}\text { Labyrinthula sp. AN-1565 } \\
\text { AB022105 } \\
(93 \%)\end{array}$ \\
\hline $\begin{array}{l}\text { Mucus } \\
\text { (pipette) }\end{array}$ & Specific & DQ073059 & 593 & $\begin{array}{l}\text { Stramenopiles } \\
\text { Labyrinthulida }\end{array}$ & $\begin{array}{l}\text { Thraustochytrium } \\
\text { multirudimentale } \\
\text { AB022111 (85\%) }\end{array}$ \\
\hline $\begin{array}{l}\text { Mucus } \\
\text { (pipette) }\end{array}$ & Specific & DQ073060 & 231 & $\begin{array}{l}\text { Stramenopiles } \\
\text { Labyrinthulida }\end{array}$ & $\begin{array}{l}\text { Labyrinthula sp. } \\
\text { L59 AB095092 } \\
(84 \%)\end{array}$ \\
\hline $\begin{array}{l}\text { Mucus } \\
\text { (milked) }\end{array}$ & Specific & AY872259 & 616 & $\begin{array}{l}\text { Stramenopiles } \\
\text { Placididea }\end{array}$ & $\begin{array}{c}\text { Placidia cafeteriopsis } \\
\text { AB061218 }(83 \%)\end{array}$ \\
\hline $\begin{array}{l}\text { Mucus } \\
\text { (milked) }\end{array}$ & Specific & AY872263 & 580 & $\begin{array}{l}\text { Stramenopiles } \\
\text { Placididea }\end{array}$ & $\begin{array}{l}\text { Placidia cafeteriopsis } \\
\text { AB061218 }(81 \%)\end{array}$ \\
\hline
\end{tabular}


The presence of stramenopile protists in association with cnidaria is not a new phenomenon and has been previously documented (Raghukumar 1988, Raghukumar \& Balasubramanian 1991). Despite this, there is still very little morphological and taxonomic information on this group of organisms. Raghukumar (1988) used immunofluorescence to locate thraustochytrids in the perisarc and the coelenteron of the hydranth of healthy obelinid hydroid cnidarians. The labyrinthulid Aplanochytrium minuta and another protist, Corallochytrium limacisporum, have been found to occur as saprobes in scleractinian coral mucus that is high in waxes and lipids (Raghukumar \& Balasubramanian 1991).To date no microscopic and ultrastructural description of these organisms has been made. The present study is the first to describe a group of as yet unidentified but morphologically similar protists intimately associated with the fungiid coral Fungia granulosa. Moreover, we found morphologically similar microorganisms on the surface of faviid corals (authors' unpubl. results).

Some members of the stramenopiles (e.g. labyrinthulomycete) are believed to have parasitic, mutualistic or saprobic associations with marine plant and animal tissues (Porter 1989, Leander \& Porter 2001). Some genera of this group, e.g. aplanochytrids and thraustochytrids, have been identified as parasites in invertebrates such as cephalopods and bivalves (Bower et al. 1989a,b, Ellis et al. 1989, Leander \& Porter 2001, Raghukamar 2002), and others are believed to cause a wasting disease in a number of bivalve species (Azevedo et al. 1997, Kleinschuster et al. 1998, Ragan et al. 2000). A further example is those isolated from sponges (Ulken 1979) and infected cnidarian cell lines (Frank et al. 1994).

To live as successful epibionts on living marine plants, stramenopiles such as thraustochytrids or labyrinthulids must be capable of rapidly utilizing dissolved organic nutrients that are released on the surface of aquatic plants, before these leach away into the surrounding water (Austin 1988). The mouth of the relatively flat fungiid corals is a site of nutrient exchange; thus, it is possible that the appearance of large numbers of these stramenopile protists surrounding the mouth opening may be a result of their utilization of the coral host as a food source, perhaps feeding on released mucus or decaying cells. Coral species with massive and flattened morphologies permit the corals to amass particulate matter on their surface via their mucus layer (Schlichter \& Brendelberger 1998, Goldberg 2002). The appearance of large concentrations of this group of protists on the surface of coral species with massive and flattened morphologies (e.g. Fungiidae and Faviidae) (authors' pers. obs.) may be possible because of the surface morphology and the amassed particulate matter.
The corals may benefit from their association with the protists via direct predation or by utilization of some biochemical abilities. Some protist species are known to recycle organic substance and to produce a number of important nutrients (Lewis et al. 1999). Several stramenopiles, for example thraustochytrids, are known to produce PUFA (polyunsaturated fatty acid) and a number of caretonoids (Carmona et al. 2003). It is thus possible that the organisms described in the present study supply the coral with supplemental nutrients explaining the longevity of bleached Fungia granulosa in the laboratory and the regeneration capabilities of the tissue balls. This hypothesis may be strengthened by the fact that these organisms were also present in the coral gastrodermal layer, in areas devoid of zooxanthellae. The persistence of these microorganisms on the coral surface during bleaching may also explain why massive corals survive bleaching better than branched corals (Loya et al. 2001) and why fungiid corals are also known to survive bleaching episodes (Hoeksema 1991, present study). It is possible that these stramenopile protists may aid their coral hosts in acquiring enough nutrients or provide an additional food source until they recover from stress such as tissue loss and bleaching events.

Acknowledgements. This work was supported by ISF grant no. 511/02-1. We thank A. Shoob for his help with the photography, J. Delara (Tel Aviv University), R. Jeger and Y. Lichtenfeld (Ben Gurion University) for their help with EM and F. Erusalinsky for his assistance with coral culturing and maintenance.

\section{LITERATURE CITED}

Anthony KRN (1999) Coral suspension feeding on fine particulate matter. J Exp Mar Biol Ecol 232:85-106

Anthony KRN (2000) Enhanced particle-feeding capacity of corals on turbid reefs (Great Barrier Reef, Australia). Coral Reefs 19:59-67

Anthony KRN, Fabricius EF (2000) Shifting roles of heterotrophy and autotrophy in coral energetics under varying turbidity. J Exp Mar Biol Ecol 252:221-253

Austin B (1988) Marine microbiology. Cambridge University Press, Cambridge

Azevedo C, Corral L (1997) Some ultrastructural observations of a thraustochytrid (Protoctista, Labyrinthulomycota) from the clam Ruditapes decussatus (Mollusca, Bivalvia). Dis Aquat Org 31:73-78

Bower SM, McLean N, Whitaker DJ (1989a) Mechanism of infection by Labyrinthuloides haliotidis (Protozoa: Labyrinthomorpha), a parasite of abalone (Haliotis kamtschatkana) (Mollusca: Gastropoda). J Invertebr Pathol 53:401-409

Bower SM, Whitaker DJ, Voltolina D (1989b) Resistance to ozone of zoospores of the thraustochytrid abalone parasite, Labyrinthuloides haliotidis (Protozoa:Labyrinthomorpha). Aquaculture 78:147-152 
Carmona ML, Naganuma T, Yamaoka Y (2003) Identification by HPLC-MS of carotenoids of the Thraustochytrium CHN-1 strain isolated from the Seto Inland Sea. Biosci Biotech Biochem 67(4):884-888

Ellis LL, Bishop SH (1989) Isolation of cell lines with limited growth potential from marine bivalves. In: Mitsuhashi J (ed) Invertebrate cell system application. Vol 2. CRC Press, Boca Raton, FL, p 243-251

Ferrier-Pagès C, Gattuso J (1998) Biomass, production and grazing rates of pico- and nanoplankton in coral reef waters (Miyako Island, Japan). Microb Ecol 35(1): $46-57$

Frank U, Rabinowitz C, Rinkevich B (1994) In vitro establishment of continuous cell cultures and cell lines from ten colonial cnidarians. Mar Biol 120:491-499

Goldberg MW (2002) Feeding behavior, epidermal structure and mucus cytochemistry of the scleractinian Mycetophyllia reesi, a coral without tentacles. Tissue Cell 34(4): $232-45$

Harvell CD, Kim K, Burkholder JM, Colwell RR and 9 others (1999) Review: marine ecology-emerging marine diseases-climate links and anthropogenic factors. Science 285(5433):1505-1510

Hoeksema BW (1991) Control of bleaching in mushroom coral populations (Scleractinia, Fungiidae) in the Java Sea: stress tolerance and interference by life-history strategy. Mar Ecol Prog Ser 74(2-3):225-237

Houlbrèque F, Tambutté E, Richard C, Ferrier-Pagès C (2004) Importance of a micro-diet for scleractinian corals. Mar Ecol Prog Ser 282:151-160

Kleinschuster SJ, Smolowitz R, Parent J (1998) In vitro life cycle and propagation of quahog parasite unknown. J Shellfish Res 17:75-78

Kramarsky-Winter E, Loya Y (1996) Regeneration versus budding in fungiid corals: a trade-off. Mar Ecol Prog Ser 134: 179-185

Kushmaro A, Loya Y, Fine M, Rosenberg E (1996) Bacterial infection and coral bleaching. Nature 380:396

Kushmaro A, Rosenberg E, Loya Y (1999) Species-specific properties of the coral mucus microbial communities. The 7th International Conference of the Israel Society for Ecology and Environmental Quality Sciences, Jerusalem

Leander CA, Porter D (2001) The Labyrinthulomycota is comprised of 3 distinct lineages. Mycologia 93(3):459-464

Lewis ET, Peter DN, McMeekin AT (1999) The biotechnological potential of thraustochytrids. Mar Biotechnol 1: 580-587

Loya Y (1978) Plotless and transect methods. In: Stoddart DR, Johannes RE (eds) Monographs on oceanic methodology. Coral reefs: research methods, Vol 5. UNESCO Press, Paris, p 197-218

Loya Y, Sakai K, Yamazato K, Nakano Y, Sambali H, van Woesik R (2001) Coral bleaching: the winners and the losers. Ecol Lett 4(2):122-131

Moss ST (1986) Biology and phylogeny of the Labyrinthulales and Thraustochytriales. In: Moss ST (ed) The biology of

Editorial responsibility: Otto Kinne (Editor-in-Chief), Oldendorf/Luhe, Germany marine fungi. Cambridge University Press, Cambridge, p 105-129

Naganuma T, Takasugi H, Kimura H (1998) Abundance of thraustochytrids in coastal plankton. Mar Ecol Prog Ser 162:105-110

Paul JH, DeFlaun MF, Jeffrey WH (1986) Elevated levels of microbial activity in the coral surface microlayer. Mar Ecol Prog Ser 33:29-40

Porter D (1989) Phylum Labyrinthulomycota. In: Margulis L, Corbiss JO, Melkonian M, Chapman DI (eds) Handbook of Protoctista. Jones \& Bartlett, Boston, MA, p 388-397

Ragan MA, MacCallum GS, Murphy CA, Cannone JJ, Gutell RR, McGladdery SE (2000) Protistan parasite QPX of hardshell clam Mercenaria mercenaria is a member of the Labyrinthulomycota. Dis Aquat Org 42:185-190

Raghukumar S (1988) Detection of the thraustochytrid protist Ulkenia visurgensis in a hydroid, using immunofluorescence. Mar Biol 97:253-258

Raghukumar S (2002) Ecology of the marine protists, the Labyrinthulomycetes (Thraustochytrids and Labyrinthulids). Eur J Protistol 38:127-145

Raghukumar S, Balasubramanian R (1991) Occurrence of thraustochytrid fungi in corals and coral mucus. Indian $\mathrm{J}$ Mar Sci 20:176-181

Ritchie KB, Smith WG (1997) Physiological comparison of bacterial communities from various species of scleractinian corals. Proc 8th Int Coral Reef Symp 1:521-526

Rohwer F, Breitbart M, Jara J, Azam A, Knowlton N (2001) Diversity of bacteria associated with the Caribbean coral Montastraea franksi. Coral Reefs 20:85-91

Rohwer F, Seguritan V, Azam A, Knowlton N (2002) Diversity and distribution of coral-associated bacteria. Mar Ecol Prog Ser 243:1-10

Rosenfeld M, Bresler V, Abelson A (1999) Sediment as a possible source of food for corals. Ecol Lett 2(6):345-348

Santavy DL, Peters EC (1997) Microbial pests: coral disease in the western Atlantic. Proc 8th Int Coral Reef Symp 1:607-612

Schlichter D, Brendelberger H (1998) Plasticity of the scleractinian body plan: functional morphology and trophic specialization of Mycedium elephantotus (Pallas, 1766). FACIES 39:227-242

Sebens PK (1994) Biodiversity of coral reefs: what are we losing and why? Am Zool 34:115-133

Sorokin YI (1973a) Trophical role of bacteria in the ecosystem of coral reef. Nature 242:415-417

Sorokin YI (1973b) On the feeding of some scleractinian corals with bacteria and dissolved organic matter. Limnol Oceanogr 18:380-385

Sorokin YI (1978) Microbial production in the coral-reef community. Arch Hydrobiol 83:281-323

Sorokin YI (1990) Aspects of trophic relation, productivity and energy balance in coral-reef ecosystem. In: Dubinsky Z (ed) Coral reefs. Elsevier, Amsterdam, p 401-410

Ulken A (1979) Pilze aus marinen Schwämmen. Veröff Inst Meeresforsch Bremerhav 17:199-204

Submitted: June 22, 2005; Accepted: February 6, 2006

Proofs received from author(s): June 21, 2006 